\title{
WILD LIFE IN SEYCHELLES
}

\section{By Desmond Foster-Vesey-FitzGeratd}

The tiny British colony of Seychelles lies in the midst of the Indian Ocean 900 miles east of Africa. The Islands are unique in being the only oceanic islands composed of continental rocks. They are fragments of a lost continent, a fact reflected in their possession of a whole group of archaic legless amphibians which have only survived as rare relics in the outside world. But besides these obscure creatures which are only of interest to the specialist, there are several other endemic species both of animals and plants, that have happily survived till the present time.

The story of the wild life of small islands is so frequently marred by records of extermination that the continued existence of the fauna of Seychelles makes a pleasant exception and the steps taken for its preservation are a credit to the colony.

The only mammals which have ever lived in the islands are bats. The most interesting of these is the flying fox which is still very abundant. These great bats spend the daytime in "camps" among the trees of the more secluded parts of the woods. They are in the habit of taking flights in the sunshine and, as they soar round the summits or travel with steady wing beats over the forest canopy, they rival birds of prey in the magnificence of their aerial manouvres. At dusk the flocks assemble round fruiting trees and squabble noisily at their feast. When occasion arises they even travel several miles across the sea to small islands for their food. The "chauve souris" is relished as human food, but even though many are shot upon occasion at the favourite tree the species is in no danger of extermination since some of the most populous "camps" are located in government reserves.

It may be noticed before leaving the mammals that the sea cow or dugong was reported around the islands by early visitors but none have survived within living memory.

Fourteen species of land birds, all of them endemic, have been recorded from the islands. All except a little green parakeet survive. It is true that of two species of white eye and two species of sunbirds formerly recorded only one kind of each is recognized to-day, but this may be due rather to the systematists view of specific characteristics than to the loss of a species through extermination. To set against this, new races of sunbirds have only this year been discovered on some of the outlying islands of the colony. 
The black parrot is one of the most interesting native birds. It is found only on Praslin Island and there only in one valley where it spends its time among the remarkable coco-de-mer palms, themselves unique and fortunately preserved in a nature sanctuary. As soon as a visitor enters the sanctuary the whistling of the parrots is sure to be heard and it will certainly not be long before one of them will be seen close at hand, for they know no fear of mankind. Parrots are usually gaudy birds and so it may be a disappointment to find that the Seychelles species is a dark grey colour; it might easily be mistaken for a hawk. Sombre plumage is a characteristic of island birds and many of the Seychelles species lack the bright colours of their relatives elsewhere. An exception to this rule is the pigeon hollandais which is now strictly preserved and may be seen wherever a wild fig tree is in fruit. This is a dark blue bird with a silvery grey head and neck and bright red wattles on the face. Like other pigeons it is in the habit of indulging in an aerial display, which consists of an upward flight followed by a downward glide, and it is a lovely sight to watch these performances in the steep-sided valleys of the islands.

Tropical birds are not remarkable for their songs but the pie chanteuse vies with any temperate species in the sweetness of it note. This bird, which is almost thrush size, has a magpie's plumage. It has unfortunately died out on all the islands except one. It seems possible that rats have caused its downfall, since the one island where it survives, Frigate Island, is free from them. Furthermore it has in the past been a favourite cage bird and some captives which were carried to a distant coral island, free from rats, have established themselves there and bid fare to outlive their relatives in their native home.

Perhaps the rarest bird in the world is the petit merle des iles. This is a little warbler of no distinctive plumage and with only a weak song. But its claim to fame lies in the fact that it is confined at the present time to one tiny island of some sixty acres. Nevertheless the species appears to be in no danger of extinction since the numbers seen during a recent visit were if anything more numerous than they were a decade and a half ago. The island in question is entirely planted with coconuts, which shows that the destruction of the original forest has not in any way affected the welfare of this species.

Another native bird, the paradise flycatcher, appears to have died out or become very rare except on the island of La Digue. Here it has adapted itself to the changed conditions and may be seen in the orchards and gardens. To nest, it still frequents the 
large shady trees of the undrained marshes; if these are drained the paradise flycatcher may disappear from its last stronghold, as it has done from the other islands.

It seems that the main factor that has caused the reduction in abundance and range of the native birds of the Seychelles is competition with introduced species. Several exotic kinds have been established and some of them, such as the Indian myna, have been extremely successful and have occupied every part of the islands. But another consideration of importance has been the introduction of species which are very closely related to the native forms. The result appears to have been hybridization between the two, with the consequent loss of the true endemic race. The turtle dove, for example, is still very common in the islands but some time ago the Mauritian sub-species was liberated and now the existing birds cannot for certain be identified with the variety which was originally described by early collectors.

The Seychelles and the surrounding islands which come under the same administration, are the breeding grounds for countless seabirds. Such great numbers frequented the islands in the past that they naturally excited the cupidity of the inhabitants. Perhaps it is fair to allow the islanders thcir share of the natural resources of their land, but there was little excuse for the wholesale collection of eggs for export in barrels; especially as the product had to be so heavily treated with preservative that it was condemned on the British market as unfit for human food. The inevitable result of this practice was the serious reduction of fresh eggs for the local market and so the export of egg-yolk was prohibited.

A close season for egg collection has been in force for some years and, provided that the date is not extended, may be considered a very useful instrument for the preservation of the seabirds. However the arrival of the birds for laying depends very largely on the season. A late monsoon means a restriction of the time available for collecting eggs during the legal period. The result is frequent application to the Government for an extension of the open season. This has never been allowed for the very good reason that it takes at least two months for the young birds to be old enough to leave the islands. If the parents cannot start to incubate until half-way through the breeding season, there is only just sufficient time for them to get clear before the monsoon drops. The great heat which follows kills any fledglings which are still landbound.

The most important egg-bird of the islands is the sooty tern 
and the above remarks apply chiefly to this species. Formerly it nested in millions on many of the sand cays but to-day the packs have been sadly reduced. However the species is in no immediate danger of being exterminated and it may be hoped that enlightened legislation will result in its returning to all its former haunts. The other sea birds are still plentiful although the eggs of many and the fat young of some are collected as food. During the post-war years several islands have been proclaimed as sanctuaries, including the large atoll of Cosmoledo, and there is now every prospect that the seabird population will be maintained at a satisfactory level.

There has, however, been one serious loss namely the rare Abbott's booby which formerly nested on Assumption Island. This bird was butchered by labourers employed in the loading of guano and the last of the race died during pre-war years. The only other breeding ground of this species is Christmas Island near Java and its welfare there is not known.

Happily the delightful little white terns are almost domestic in their familiarity. True enough in the more inhabited parts of the islands stones of small boys have driven them into the higher trees to lay their eggs but in more out-of-the-way places they deposit their single eggs on branches and rafters within easy reach. Here the parent birds hardly bother to flutter up as one extends one's hand to stroke them.

The tameness of some of the birds in the Seychelles must be seen to be believed. Fishermen are in the habit of visiting the booby colonies and tickling the throats of the birds. This causes the foolish creatures to regurgitate their latest meal of flying fish which are then collected for bait. At Aldabra Island a charming little flightless rail is found on some of the islets in the lagoon where it is safe from the cats and rats which infest the main atoll. They can be easily attracted from the thick bush by rattling two sticks together. When they run out they show no objection to being picked up for examination and when gently replaced on the ground they hurry about their business of catching sand crabs.

No account of the fauna of Seychelles would be complete without reference to the giant tortoises. When the islands were discovered these creatures must have swarmed over most of them. They were rapidly destroyed and it is now many years since any wild ones have roamed the countryside. However they are exceptionally long lived creatures and penned specimens are common in many courtyards. They thrive and breed well in captivity provided their eggs are protected from rats, so the 
species is in no danger of extermination. Moreover they still live in the wild state on the island of Aldabra which is Government owned and where the tortoises enjoy complete protection.

The tiny island colony has done well in its efforts to protect the many unique members of its flora and fauna. Wild birds and animals have been protected by Government ordinance since 1903 and suitable laws regulate the collection of seabirds and their eggs. The catching of green turtles and the hawksbill turtle is controlled, while leaving the Colony still famous for its export of calipe and tortoise shell.

The total land area of the Colony is only 170 square miles of which five are reserves, and in addition there are six sanctuary islands. 'The most famous reserve is the Vallee de Mai in Praslin Island which was purchased by the Government in 1946. There the unique coco-de-mer and other species of endemic palms are protected from vandalism and fire, while the shady groves provide a home for many of the native birds and delightful scenery for the lucky visitor to those charming islands.

Birds mentioned in the article

Seychelles black paradise-flycatcher (Tchitrea corvina), Pie chanteuse or Seychelles magpie-robin (Copsychus seychellarum), Petit merle des iles (Benrornis seychellensis), Black parrot (Coracopsis barklyi), Pigeon hollandais (Alectroenas pulcherrima), Turtle dove (Streptopelia picturata rostrata), Flightless rail (Dryolimnas aldabranus), Abbott's booby (Sula abbotti), Sooty tern (Sterna fuscata), White tern (Gygis alba). 